Nadwa : Jurnal Pendidikan Islam

Vol. 14, No.1 (2020)

Accredited by Ristekdikti based on Decree No. 51/E/KPT/2017

DOI: 10.21580/nw.2020.14.1.5979

\title{
Learning Innovation with Mobile Devices ICT \\ In Majlis Ta'lim Raudhotun Nisa Jakarta, Indonesia
}

\section{Heni Ani Nuraeni}

\section{UHAMKA}

Email : henianinuraeni@uhamka.ac.id.

\begin{abstract}
:
Information Communication Technology (ICT) is a public demand in the industrial era 4.0. This study examines the use of mobile devices (ICT) in learning at the Majlis Ta'lim Raudhatun Nisa, Jakarta, Indonesia. Majlis ta'lim is a conventional Islamic educational institution for studying and practicing religious knowledge. The results of the study found that the majlis ta'lim Raudhotun Nisa was quickly responds to the demands of the times by making basic learning innovations. Learning does not only use conventional media but has used mobile devices in the form of projectors, laptops, and smartphones including WhatsApp, Facebook, and Instagram. Although most of the participants are elderly people who are not tech-savvy yet, the use of mobile devices has served as a means of socialization and communication and an effective means of modern learning.
\end{abstract}

Keywords: Innovation; Learn; Majlis Ta'lim;, Cellular Devices, ICT, modern learning

\begin{abstract}
Abstrak:
Teknologi Komunikasi Informasi (TIK) merupakan tuntutan masyarakat di era industri 4.0. Penelitian ini mengkaji pemanfaatan perangkat seluler (TIK) dalam pembelajaran di Majlis Ta'lim Raudhatun Nisa, Jakarta, Indonesia. Majlis ta'lim adalah lembaga pendidikan Islam konvensional untuk mempelajari dan mengamalkan ilmu agama. Hasil penelitian menemukan bahwa majelis ta'lim Raudhotun Nisa dengan cepat merespon tuntutan zaman dengan membuat inovasi pembelajaran dasar. Pembelajaran tidak hanya menggunakan media konvensional tetapi telah menggunakan perangkat mobile berupa proyektor, laptop, dan smartphone termasuk WhatsApp, Facebook, dan Instagram. Meski sebagian besar pesertanya adalah lansia yang belum paham teknologi, penggunaan perangkat seluler telah berfungsi sebagai sarana sosialisasi dan komunikasi serta sarana pembelajaran modern yang efektif.
\end{abstract}

Kata kunci: Inovasi; Belajar; Majlis Ta'lim ;, Perangkat Seluler, TIK, pembelajaran modern

ISSN 1979-1739 (P) ; ISSN 2502-8057 (E).

(C) 2020 Nadwa : Jurnal Pendidikan Islam | UIN Walisongo.

Accredited by Ristekdikti based on Decree No. 51/E/KPT/2017

http://journal.walisongo.ac.id/index.php/nadwa 


\section{Introduction}

Majelis ta'lim is a type of non-formal and community-based education. This is reinforced by Law No. 20 of 2003 concerning the National Education System Article 26, that non-formal education is held for citizens who need educational services serves as the substitute, addition, and or complementary formal education to support lifelong education.

The Grand Imam of the Istiqlal Mosque in Jakarta said that there were approximately 250,000 majelis ta'lim in 2018, and most of them took place at the mosque because it is a gathering place, the basis for commencement of instructions and an effective learning place.1 Meanwhile, the number of majelis ta'lim in Jakarta are 5674 units.

Table 1. Number of Majelis Ta'lim in DKI Jakarta in 2017

\begin{tabular}{cll}
\hline Number & \multicolumn{1}{c}{ Place } & Sum \\
\hline 1. & South Jakarta & 1.617 \\
\hline 2. & West Jakarta & 1.365 \\
\hline 3. & East Jakarta & 1.247 \\
\hline 4. & Central Jakarta & 760 \\
\hline 5. & North Jakarta & 625 \\
\hline 6. & Kepulauan Seribu & 60 \\
\hline \multicolumn{2}{c}{ Total } & 5.674 \\
\hline
\end{tabular}

1 Phillip Winn, "Women's Majelis Taklim and Gendered Religious Practice in Northern Ambon," Intersections: Gender and Sexuality in Asia and the Pacific 30 (2012): 1-15. 
Source: Document of Regional Office of Ministry of Religion of DKI Jakarta Province in 2017

Tuty Alawiyah said that, in general, majelis ta'lim is a purely non-governmental organization.2 It was found, managed, nurtured, developed, and supported by its members. Therefore, the majelis ta'lim are a community forum to meet their own needs. The majelis ta lim will benefit the congregation if their needs are met. It is essential for the preacher to recognize their needs, so he/she can adjust or direct the congregation to the goals to be achieved. The majelis ta'lim will meet the needs of the congregation according to its roles. The majlis ta'lim serves as a place to provide additional knowledge and abilities, organize contact and social relations, realize common social interests, and encourage the awareness and practice for the welfare of household life. In other hand, Philip said that The core practices shared by majelis taklim involve prayer and the use of one or more Arabic-language religious texts. This does not mean that all or even any of the participants in a given gathering are able to understand Arabic. Texts are frequently recited rather than translated or discussed. Another general feature is an educative dimension. Participants usually view majelis taklim as enhancing their proficiency in being Muslim in some respect. This might involve gaining direct advice from a respected figure on living a more devout life, improving skills in religious practice, or enlarging one's knowledge of theological interpretation. 3

If there are differences between one majelis ta'lim and another, this is not due to their functions, but the differences in

2 Tuty Alawiyah, "Strategi Dakwah Di Kalangan Majelis Ta'lim" (Bandung: Mizan, 1997).

3 Rika Erliyana and Samsul Huda, "Actualization of Pancasila Values (Indonesian Ideology) in Majelis Taklim Organization," Al-Hayat: Journal of Islamic Education 3, no. 1 (2019): 68-81. 
the environment of the congregation where the majelis ta'lim located, their management and the content of the materials being taught. 4 While Yusri Abady mentioned several functions of the majelis ta'lim, including the means to convey religious messages efficiently and effectively to participants, the means to exchange opinions and experiences of participants, and the means to foster close relationship in the ukhuwah Islamiyah (brotherhood among fellow muslims).5 In line with Yusri, Nur Setiawati in Imamul Huda, said that the existence of the majelis ta'lim has brought benefits and positive impacts for the community, especially for Muslim women.6

The results of Rosehan Anwar's research showed that there are seven benefits of participating in the majelis ta'lim, including (1) improving the ability to read the Qur'an, (2) increasing religious knowledge; (3) increasing the awareness to practice religious teachings; (4) increasing the worship, (5) improving the morals, (6) expanding networks, (7) encouraging to improve the spiritual and physical quality. Of the seven benefits, $46 \%$ of the congregation said that the greatest benefit is to increase the awareness to practice religious teachings. The second most popular benefit is to increase religious knowledge (20\%), followed by increasing the worship (12\%), encouraging to improve the spiritual and physical quality (12\%) and improving the morals $(10 \%)$. Thus, the biggest benefit people gained is

4 Tuty Alawiyah, "Manajemen Majelis Taklim" (Jakarta: Pustaka Intermasa, 2009).

5 Yusry Abadi, Pengembangan Wawasan Keagamaan Melalui Majlis Ta'lim Di Bandar Lampung (Jakarta: Balitbang Agama dan Diklat Keagamaan, 2002).

6Imamul Huda, "Pemberdayaan Masyarakat Berbasis Multikultural Di Majelis Taklim An Najach Magelang," INFERENSI: Jurnal Penelitian Sosial Keagamaan 13, no. 2 (2019): 253-78. 
increasing the awareness in practicing religious teachings.7 The detail is presented in Table 2

Table 2. The Perceived Benefits of the Congregation

\begin{tabular}{lll}
\hline \multicolumn{1}{c}{ Types of Benefits } & Frequency & Percentage \\
\hline Increasing religious knowledge & 10 & 20 \\
\hline $\begin{array}{l}\text { Improving the ability to read the } \\
\text { Qur'an }\end{array}$ & - & - \\
\hline $\begin{array}{l}\text { Increasing the awareness to } \\
\text { practice religion }\end{array}$ & 23 & 46 \\
\hline $\begin{array}{l}\text { Increasing the worship } \\
\text { Improving morals }\end{array}$ & 6 & 12 \\
\hline Expanding networking & - & 10 \\
\hline $\begin{array}{l}\text { Encouraging to improve } \\
\text { spiritual and physical qualities }\end{array}$ & 6 & - \\
\hline Sum & $\mathbf{5 0}$ & 12 \\
\hline
\end{tabular}

Table 2 shows that majelis ta'lim has many benefits for the congregation, not only increasing insight and skills in worship, but also also increasing social interaction, and fostering awareness to practice the religion. These benefits are inseparable from the Islamic concept of lifelong learning.

However, there are some problem in the implementation process of learning in majelis ta'lim. In general, the problems faced by the majelis ta'lim are related to the content of the materials and the delivery of speeches or lectures that are less interesting and less relevant to actual problems or environmental needs. In addition, the power to analyze the situations and conditions as well as the ability to find solutions to problems has

7 Rosehan Anwar, Majelis Taklim Dan Pembinaan Umat (Puslitbang Lektur Keagamaan, Balitbang Agama dan Diklat Keagamaan ..., 2002). 
not been accurate nor systematic. 8 In addition, the the management of majelis ta'lim is still traditional, as revealed by Kulsum Minangsih. She said that most majelis ta'lim are traditionally managed, where the management uses previous experiences that are always based on tradition. Besides, it also applies the merit approach and the concept of lillahi ta'ala (only because of Allah). Thus, sometimes it ignores the quality of the materials and is not adapted to the needs of the congregation. This management method must be changed by introducing a good new management, namely by improving the quality of the preachers or teachers (ustadz and ustadzah), the curriculum, the methodology and infrastructure. 9

In the context of learning, the majelis ta'lim differs in their implementation of the objectives, the materials, the learning methods, the teachers (ustadz and ustadzah), the infrastructure, and the learning evaluation. This research aimed to describe learning innovations in majelis ta'lim through mobile devices (a case study of majlis ta'lim Raudhatun Nisa). The mobile devicebased learning activities in this study can be interpreted as learning innovations that can increase the motivation and insight of congregation in learning, enhance the existence of majlis ta'lim as centers of Islamic $d a^{\prime} w a h$ (preaching) to reach a wider community.

\section{The Nature of Learning Innovation}

8 Kamaluddin Kamaluddin, "Mesjid Dalam Meningkatkan Keagamaan Masyarakat Melalui Majelis Taklim Di Kota Padangsidimpuan," Tadbir: Jurnal Manajemen Dakwah FDIK IAIN Padangsidimpuan 1, no. 1 (2019): $17-32$.

9 Kalsum Minangsih, "Paradigma Baru Pengelolaan Institusi Dakwah: Urgensi Ilmu Manajemen Mewujudkan Majelis Taklim Ideal," Kontekstualita: Jurnal Penelitian Sosial Keagamaan 29, no. 2 (2014): 145910. 
Learning innovation consists of two syllables: Innovation and learning. Innovation, according to the Big Indonesian Dictionary (Kamus Besar Bahasa Indonesia), is the introduction of new things, renewals, new discoveries that are different from those introduced before.10 Subandi explained that the etymologically, innovation was originated from Latin, innovation, that means renewal or change towards improvement. Thus, innovation is a process of renewal or change towards improvement. In other words, innovation is a process of renewal in the elements of a community's culture, namely technology. So, innovation means new discoveries in human technology. While in a broader sense, innovation is a renewal of various resources so that it has greater benefits for humans and the its process is influenced by the progress of science and technology.11

In Umul Hidayati, Sa'ud explained that innovation is an idea, method, way, and man-made goods, which are observed and felt as something new for someone/society; it is in the form of intervention or recovery, that is used to achieve goals or solve the problem.12

Thus, it can be concluded that innovation is a new idea or something that has not yet existed previously and is useful to improve service or productivity. One who find something new is called an innovator. Thus, innovative people will always make improvements to enhance services and productivity. In nonformal education, such as majelis ta'lim, innovation is needed.

10 Setiawan Ebta, "Kamus Besar Bahasa Indonesia," KBBI Offline, 2015. Hal 212

11 Muhammad Subandi, "Developing Islamic Economic Production," Science Technology and Development 31, no. 4 (2011): 348-58.

12 Umul Hidayati, "Inovasi Madrasah Melalui Penyelenggaraan Madrasah Riset," Edukasi 17, no. 3 (2019): 294679. 
The innovations in learning include materials, methods, media, and learning evaluations.

Talking about learning in an education concept means learning and instruction. The concept of learning is rooted on students and the concept of instruction is rooted on the teachers. Both can stand alone or unite, depending on the situation of the two activities. Learning usually takes place in a formal situation deliberately programmed by the teacher to transform the knowledge to students and is based on the curriculum and objectives. Learning is centered on the objectives to be achieved based on the plan. Hence, learning is a process that makes a person or a number of people (students) do the learning process based on the teaching plan programmed. The intentional element, through the teacher's planning, is carried out systematically, following fully systematic steps by taking into account various aspects.13 So, learning is a complex process that happens to everyone and lasts a lifetime. One of the signs that someone has learned is a change in their behavior. Changes in behavior involve the changes of knowledge (cognitive) and skills (psychomotor) as well as those concerning values and attitudes (affective).

Learning activities involve several components, namely: students, teachers, learning objectives, the content of the lessons, teaching methods, media and evaluation. Students are a group of people acting as receivers and depositors of the content of the lessons needed to achieve the goal. The teacher is a person or group of people who conduct the teaching and learning activities and have other roles that enable effective teaching and learning activities through transformation. Meanwhile, an objective is a statement of the desired behavior change (the modification of

13 Dkk Aminuddin, "Pendidikan Agama Islam Untuk Perguruan Tinggi Umum,” Bogor: Ghalia Indonesia, 2002. hal. 35 
evert behavior) to occur in students after participating in the teaching and learning activities. The contents of the lessons are all information in the form of facts, the principle concepts and educational messages needed to reach the objectives. On the other hand, method is a variety of regular and systematic ways carried out by teachers in providing opportunities for students to get the contents they need. Media is a set of educational and teaching equipment used to help presenting the content and subject matter to students so that they can achieve their goals. Evaluation is a set of assessment tools used to assess the learning process and its outcomes.14 All components of teaching and learning activities above are interconnected to reach the learning objectives.

\section{The Concept of the Majelis Ta'lim}

Majelis ta'lim is derived from Arabic, jalasa yajlisu, ijlis, majalisin (isim makan), which means a place to sit or a place to sit together to complain or exchange ideas. While ta'lim comes from the word 'allama yиa'llimu i'lam ta'liman (isim masdar) which means learning. So, the majelis ta'lim can be defined as a place to sit together to carry out learning informally led by a number of religious teachers (ustadz or ustadzah). Majelis ta'lim can be interpreted as a forum for the development of the ummah to understand Islamic teachings textually and contextually. 15

Asrohah said that the majelis ta'lim are an institution that organizes a place for teaching and learning of Islam. Similarly, Hasbullah said that the majelis ta'lim is a place to conduct

14 Rasyad Aminuddin, "Teori Belajar Dan Pembelajaran," Jakarta: UHAMKA Press \& Yayasan PEP-Ex 8 (2003).

15 Abadi, Pengembangan Wawasan Keagamaan Melalui Majlis Ta'lim Di Bandar Lampung. 
Islamic teaching or recitation. Thus, the majelis ta'lim is a place to study Islam informally and also to expand social interaction. 16 Majelis ta'lim is one of the da'wah organizations that grows and develops in Indonesia, including in Jakarta. In Encyclopedia of Islamic, majelis ta'lim is non-formal Islamic educational institutions conducting Islamic studies. This institution is developed in the Muslim community in Indonesia, both in Jakarta and in other regions. The naming of majelis ta'lim is more commonly found in Jakarta, especially among Betawi people, while in other areas, it is known as "an Islamic religious study". Although the word majelis ta'lim is derived from Arabic, the term itself is not used in Arabic society. 17

Rosidin said that the majelis ta'lim was a powerful means to empower the community, both in the religious field and in the political, economic and social fields. In the political aspect, majelis ta'lim plays an important role in the integrity of the Unitary State of the Republic of Indonesia. It protects from the threat of national disintegration, at least from the smallest scope of the family and surrounding communities. In the economic aspect, majelis ta'lim can be used to improve the economy, for example by forming regular social gathering, cooperatives and others. In the social aspect, majelis ta'lim can foster a sense of solidarity (ukhkuwah) between individuals in the community so that they are not easily provoked by issues that can trigger social conflicts. 18

16 Huda, "Pemberdayaan Masyarakat Berbasis Multikultural Di Majelis Taklim An Najach Magelang."

17 Juan Eduardo Campo, Encyclopedia of Islam (Infobase Publishing, 2009). Hal. 213

18 Rosidin Rosidin, "INDEKS PERAN PENYULUH AGAMA DALAM MEMBINA KEHIDUPAN BERAGAMA KELUARGA MAJELIS TAKLIM DI KABUPATEN SRAGEN JAWA TENGAH Index of The Roles of Religion Extension Agent on Guiding Religious Life for Majlis Taklim in 
The above opinions shows that majelis ta'lim has broad functions for the development of society, not only enriching the insight and religious skills but also contribute to economic, social and political fields. Therefore, majelis ta'lim must be managed professionally. One of them is by improving the learning through mobile devices.

\section{Learning of The Majlis Ta'lim}

Firman Nugraha in the jurnal Bimas Islam vol. 9 No. 111 of 2016, said that majelis ta'lim, in its learning, not only teaches religious knowledge but also develops the learning of economic empowerment of its members; however, it needs coaching in term of the management. Meanwhile, according to the research results of the Center for Research and Development of Religious Literature (Pusat Penelitian dan pengembangan Lektur Keagamaan), the learning materials between majlis ta'lim is different and has its own characteristics. For example, in the majelis ta'lim of Ahlu As sunah Al Jamaah in Palembang, 70\% said that the most preferred learning is the discussion of the books, such as the interpretation of Qur'an, Hadith, Islamic history, the character of Sufism and fiqh (Islamic jurisprudence), while $30 \%$ preferred listening to religious lectures. Whereas, in majelis ta'lim of Darut Tauhid in Bandung, the most preferred learning is listening to religious lectures (60\%), followed by questions and answers about religion (26\%) and preaching or development (14\%).19

As for the majelis ta'lim in Jakarta, for example, the majelis ta'lim of Asy Syafiiyah, it not only deepen the religious

Sragen District Central Java," Jurnal SMART (Studi Masyarakat, Religi, Dan Tradisi) 3, no. 1 (2017): 79-89.

19 Firman Nugraha, "Peran Majlis Taklim Dalam Dinamika Sosial Ummat Islam,” Jurnal Bimas Islam Kemenag RI 9 (2016). Hal. 105-112 
knowledge and praising the prophet (sholawat) but also emphasizes the development of the teachers (ustadz or ustadzah). Most members of the congregation of this majelis ta'lim (75\%) are $u s t a d z$ (female teachers) and ustadzah (male teachers). They come from various regions and represent the majelis ta'lim in their respective regions. The other learning of this majlis ta'lim is developing skills to support da'wah. Therefore, a book about da'wah was published, for example, Bimbingan tabligh dan Doa (Guidance to the Tabligh and Prayer) (Ministry of Religion Research and Development Agency, 2002). So, the learning of majelis ta'lim will be tailored to the objectives, learning materials, methods, infrastructure, and religious teachers (ustadz and ustadzah).

\section{The Objectives of the Majelis Ta'lim}

The objectives of between one majelis ta'lim to another is different. Tuty alawiyah said that the objectives of the majelis ta'lim are varied, because the founders of the majelis ta'lim, organizations or management, environment, and congregation are different. The founders of the majelis ta'lim never write their purposes. Tuty formulated that the objectives can be seen from its functions, including: first, the majelis ta'lim serves as a place to study, so the aim is to increase knowledge and religious beliefs which will ultimately encourage the practice of religious teachings; second, it serves as a social contact, so the goal is friendship; third, it serves to realize social interests so the aim is to increase awareness and welfare of the household and the environment of the congregation. 20

\section{Learning Materials in Majelis Ta'lim}

20 Alawiyah, "Strategi Dakwah Di Kalangan Majelis Ta'lim.” 
Learning materials in the majelis ta'lim are not given daily, like formal schools, but the learning can be weekly, twice a week and three times a week, depending on the policy of the leader of the majelis ta'lim. Therefore, Tuty Alawiyah classified the types of majelis ta'lim based on the material taught. First, the majelis ta'lim that does not teach regularly, instead it only serves as a gathering place, reciting prayers together, reading surah yasin, commemorating teh Prophet's birthday, and doing the sunnah (voluntary) praying in congregation. Once a month, the management of majelis ta'lim invites a teacher to give a lecture and this lecture is the content of the majelis ta'lim. Second, the majelis ta'lim which teaches religious knowledge about figh, monotheism, and morals, it provides the material in preaching and sometimes it also has questions and answers session. Third, majelis ta'lim which teach basic knowledge and skills of religious teachings, such as learning how to read the Qur'an, or fiqh of learning how to pray and others. Fourth, majelis ta'lim that teach certain books and the book is a textbook used by the teachers (ustadz or ustadzah) and congregation. Fifth, the majelis ta'lim that teach by lectures and the subject matter, adapted to current situations based on Islamic teachings, are given in written texts. 21

\section{The learning Method of Majelis Ta'lim}

The learning methods used include reading together, imitating, lecturing and discussing (in a question and answer session). In the larger group, the tabligh method is used. Tabligh is one of the da'wah method. The method of preaching is tabligh, publishing, providing examples and joint observation.22 Learning in the majelis ta'lim covers learning objectives that are adjusted

21 Alawiyah.

22 Alawiyah. 
to the functions of the majelis ta'lim. Besides, the learning materials are also adjusted to the needs of congregation and the objectives of the majelis ta'lim. Generally, the learning methods used is the lecture of the preachers, the question and answer, and also the demonstration. Learning evaluation is carried out indirectly but not systematically, using non-test instrument, carried out after the learning. The place used by majelis ta'lim to study is mostly mosques but some use special buildings.

\section{Mobile devices in Learning}

In this global era, students, including the congregation of majelis ta'lim, are generally technology literate and are familiar with mobile devices. Mobile devices come from two words, device and mobile. Device means equipment, mobile is lighthanded or portable. Mobile devices include mobile phones, smartphones, cellphones.23 According to data from Hootsuite (social media content management site), the internet and social media users in Indonesia, by the end of January 2019, are 150 million (increasing by $13 \%$ from 2018) and the active social media users are 150 million (increasing by $15 \%$ from 2018 ). The number of users is fantasti and indicates that one person can have more than one smartphone. No wonder Indonesia has become one of the lucrative markets for mobile application developers in the world.24

Specifically, the categories of mobile applications are as follows; 1) Communication, this application can be used to communicate easily, 2) Education, this application contains educational content, such as mathematical formula and others. 3)

23 Anealka Aziz Hussin, "Education 4.0 Made Simple: Ideas For Teaching.," International Journal of Education and Literacy Studies 6, no. 3 (2018): 92-98.

24 Hussin. 
News and magazines, this application enables people to read news easily. 4) Games, this application is used to kill boredom by playing games. 5) Social networking, this application enable people to exist and connect with others.

The above applications requires you to register at Play Store. The following are the the most popular applications in Indonesia; 1) WhatsApp, this application enable people to send to send messages for free as well as make a call and video call easily. 2) Facebook, this application enable people to connect with many people around the world. 3) YouTube, it is the largest video sharing application in the world. 4) Instagram, this application is to share photos with the world.

Especially mobile device more important in learning at the time. Mobile device became central media in educational instituti. Depend on Walsh, there are significant advantages associated with mobile learning. These include high access, low cost, more situated and contextual learning, convenience for the learner, continuous communication and interaction between learner and tutor and between learner and other learners, and the ability to self-assess themselves while learning. 25

\section{Research methods}

This research used a descriptive qualitative research method. Researchers focus on actual problems through data collection, data arrangement, and data analysis.26 In addition, researchers use informants as sources of data to obtain information. The

25 Kieran Walsh, "Mobile Learning in Medical Education," Ethiopian Journal of Health Sciences 25, no. 4 (2015): 363-66.

26 J Moelong, “Lexy. 2012," Metode Penelitian Kualitatif. Bandung: PT Remaja Rosdakarya, n.d. 
informants used in this study came from internal and external sources. Internal sources were used to obtain information and data needed that were directly related to research. They were the leader and the management of the majelis ta'lim. The external source were used to complete the data and information needed. They were chosen randomly from the congregation of the majlis ta'lim. The data collection was conducted through interviews and observations. Researchers participated in attending the learning. The data collection was also complemented by documentation techniques, documenting of the majelis ta'lim activities conducted. The data was taken from the field by participating in the learning every Monday from 13.00 to 15.00 . The research focused on learning innovations carried out by the majelis ta'lim based on mobile devices.

This research was conducted at the majelis ta'lim Raudhatun Nisa in 2019. The subject of the research was the majelis ta'lim Raudhatun Nisa, located in Palmerah, West Jakarta. The number of congregation were around 100 people from various background including: housewives, teachers, civil servants, retirees, the private employees and others.

\section{Results and Discussion}

\section{A glimpse of the majelis ta'lim Raudhatun Nisa}

Majelis ta'lim Raudhatun Nisa is located on Jl. H. Monday Palmerah West Jakarta. This majelis ta'lim is one of the excellent majelis ta'lim in DKI Jakarta, as indicated by its achievements. It won the first place in a management competition held by Ministry of Religious Affairs Regional Office of the DKI Jakarta in 2018. The learning in Majelis ta'lim Raudhatun Nisa, in 
general, is no different from others. The materials taught emphasize more on individual piety. The materials include Fiqh Safinatun Najah, Qur'an and Tajweed, Tafseer of juz Amma, Qur'an and Hadith, Rawi and Praising the prophet (Sholawat), that are delivered conceptually and in practice. 27

The curriculum used in the majelis ta'lim is not standard, even though the learning materials have been determined. The majelis ta'lim is always open to important changes, as long they do not deviate from the vision and mission of the majelis ta'lim. The vision of the majelis ta'lim Raudhatun Nisa is to realize Muslim generations who have faith, piety, and morality according to the Qur'an and Hadith. Its mission are prioritizing the sense of unity and unity of ukhuwah Islamiyah (Islamic brotherhood); showing love, gratitude and sincerity and trust in God and expecting His approval (ridho); growing love for the Prophet Muhammad by carrying out his sunnah (examples).28

\section{Learning of Majelis Ta'lim Raudhatun Nisa}

Learning activities are methodologically rooted on the teacher while pedagogical learning activities are rootedon students. In the majelis ta'lim Raudhatun Nisa, learning is rooted in teachers and students (congregation). Learning activities involve several components, including: the teachers (ustadz or ustadzah), congregation, objectives, content of the lesson, methods, media, and evaluation.

27 Dokumen Raudhatun Nisa, "Sejarah Pendirian Majlis Taklim Raudhatun Nisa" (2018).

28 Masturoh, "Interview with Masturoh Chip of Raudhotun Nisa" (Jakarta, 2019). 
Each learning activity is led by a teacher (ustadz or ustadzah) who conveys the learning. Teachers in the majelis ta 'lim teach according to their expertise and deliver the learning materials following the learning objectives to be achieved. Students (congregation) are parties who are ready to save the knowledge delivered by the teacher. The learning activities of the majelis ta'lim Raudhatun Nisa once a week, on Monday from 13:00 to15.00. table 3 presents the schedule for learning activities at the majelis ta'lim Raudhatun Nisa.29

Table 3. Learning Schedule of majelis ta'lim Raudhatun Nisa

\begin{tabular}{l|l|l}
\hline \multicolumn{1}{c|}{ Week } & \multicolumn{1}{|c}{ Learning materials } & Learning Time \\
\hline 1st Monday & Fiqh Safinatun Najah & $13.00-15.00$ \\
\hline 2nd Monday & Qur'an and Tajweed & $13.00-15.00$ \\
\hline 3rd Monday & Tafseer of Juz Amma & $13.00-15.00$ \\
\hline 4th Monday & Qur'an and Hadith & $13.00-15.00$ \\
\hline 5th Monday & Rawi and Sholawat & $13.00-15.00$ \\
\hline
\end{tabular}

Source: Documents of the majelis ta'lim Raudhatun Nisa, 2019

Learning activities on the fist Monday is fiqh safinatun najah, attended by approximately 100 people, consisting of several active majelis ta'lim. The learning is carried out at the house of one of the members who volunteers to the leader of the majelis ta'lim so that his house becomes a place of study. The learning materials for the second Monday is the Qur'an and recitation, attended by only 30 people and conducted at the majelis ta'lim Raudhatun Nisa. Whereas, the learning material for the third Monday is the tafseer (interpretation) of juz amma and it is conducted at the hall of majelis ta'lim. The fourth Monday is attended by the congregation of majelis ta'lim

29 Masturoh. 
Raudhatun Nisa and conducted at the hall, with the learning materials of the Qur'an and Hadith. If there is the fifth Monday, the learning materials will be rawi and sholawat. In the event of Islamic holidays, such as the Prophet's birthday, isra mi'raj, Islamic new year and others, the majelis ta'lim invites the famous ustadz or ustadzah. In addition, on Tuesday to Friday from 13.00 to 16-00, majelis ta'lim is used for the Qur'an Education for kids (Taman Pendidikan Al-Quran) and the teacher are staff of the majelis ta'lim Raudhatun Nisa.

\section{Learning Objectives of Majelis Ta'lim Raudhatun Nisa}

The learning objectives of the majelis ta'lim Raudhatun Nisa are in line with from the vision and mission of the institution. Tuty Alawiyah argued that the purposes of the majelis ta'lim can be seen from its function. Based on the results of interviews with the head of the majelis ta'lim Raudhatun Nisa, that the initial purpose of the majelis ta'lim was as a place to increase knowledge and religious beliefs, which encourages religious practices, as indicated from the materials taught. There are figh, learning about the procedures for worship, such as prayer, zakat, fasting, and pilgrimage, and Qur'an and recitation, learning how to read the Qur'an in accordance with the tajweed. These materials place more emphasis on individual peity.

\section{Learning Materials}

As explained earlier that learning materials provided to the congregation place more emphasis on individual piety. These materials include Fiqh Safinatun Najah, Qur'an and Tajweed, Tafseer juz Amma, Qur'an and Hadith, Rawi and Sholawat. The materials are given in accordance with the wishes and needs of the congregation. In general, the age of the congregation of majelis ta'lim is over fifty years old, thus, the above materials are 
very much needed. This majelis ta'lim is always open to innovation, including in the learning material. The congregation of majelis ta'lim have participated in lessons other than religious studies, such as Master of Ceromony (MC) training. This training was held by the majelis ta'lim Raudhatun Nisa collaborating with other educational institutions. The congregation is enthusiastic in participating in this training. 30

\section{Methods, media and learning evaluation}

The learning method is a way conducted and taken by the teachers to systematically realize the learning efforts.31 The methods used by the majelis ta'lim Raudhatun Nisa include lecture, congregation reading, imitation, and question and answer methods. Lecture method is the delivery of learning materials by communicating learning materials verbally. Lecture is one of the main methods in the majelis ta'lim, which is also called the tabligh method, conveying the material orally. The lecture method or the tabligh method is mostly applied at Islamic holidays, such as the Prophet's birthday, Isra mi'raj and the Islamic new year.

Another learning method implemented is reading together and imitating. Based on the observation, this method is closer to the demonstration method. It is a learning method by demonstrating or displaying something to students inside or outside the classroom so as to clarify their understanding. Among the demonstrations performed by congregation are how to pray and how to read the Qur'an according to tajweed or recitation as it is hard for the congregation to understand without the demonstration method. Also, the question and answer method is

30 Raudhatun Nisa, Jadwal Kegiatan Majelis Ta'lim Raudhatun Nisa (Jakarta, 2018).

31 Aminuddin, "Teori Belajar Dan Pembelajaran." 
used at the end of the lesson as the way the teacher transforms the learning materials. In this case, congregation ask questions to their teacher. This majelis ta'lim has innovations concerning questions from the congregation. They may ask questions through the application, such as WhatsApp, and the teacher is happy to answer the congregation's questions. This is the uniqueness of this majelis ta'lim, although the congregation is no longer young, but the spirit of innovation and learning is high. High enthusiasm is strengthened by interesting learning media.

Arief S mentioned that learning media are all physical forms that can deliver messages and stimulate students to learn. There are various forms of learning media, such as original objects, artificial objects, sketches, miniatures and others. The learning media used by the majelis ta'lim have experienced innovation, from teaching verbally only or using a whiteboard to using projector. In each Qur'an learning, everyone has already had the Qur'an and started using a mobile device. So, the media used by the majelis ta'lim has experienced advanced innovation, even though the age range of the congregation is no longer young. Please note that the age of the congregation of majelis ta'lim is on average above 50 years, as shown in Table 4.

Table 4. The Age Range of the Members of Majelis Ta'lim Raudhatun Nisa in 2019

\begin{tabular}{ccc}
\hline Age & Total & Percentage \\
\hline $40-50$ & 1 & $5 \%$ \\
\hline $51-60$ & 5 & $25 \%$ \\
\hline $61-70$ & 11 & $55 \%$ \\
\hline $71-80$ & 2 & $10 \%$ \\
\hline $81-90$ & 1 & $5 \%$
\end{tabular}

Source: Documents of the Majlis Ta'lim Raudhatun Nisa in 2019 In the evaluation process, the majelis ta'lim applied a nontest instrument, meaning the test is not conducted as in formal 
education. The test is carried out if the congregation joins the lesson. For example, the Qur'an reading test is conducted face to face with the Qur'an teacher. This method makes the congregation does not feel that $\mathrm{s} / \mathrm{he}$ is being tested and they feel happy when they make progress.

\section{The Uniqueness of the Council of Majelis Ta'lim Raudhatun Nisa}

Majelis Ta'lim Raudhatun Nisa has its own uniqueness compared to others. First, the majelis ta'lim have used a mobile device in their learning, such as WhatsApp and Facebook. WhatsApp is used for delivering information concerning the learning schedule, any change of the schedule, information related to the learning or other activities of majelis ta'lim, as well as for question and answer related to the learning. Facebook is used to inform the activities carried out by the majelis ta'lim, both the learning or other activities related to the majelis ta'lim. Facebook enables the Islamic da'wah carried out by the majelis ta'lim to be increasingly known to the wider community.

It is quite reasonable for this majelis ta'lim to use mobile devices in their learning. Eighty-five percent of the majelis ta'lim congregation have smart phones and several accounts. The following is the data of the number of majelis ta'lim members' cellphones and accounts.

Table 5.. Data on the Number of Cellphones and Accounts of the Majelis Ta'lim Raudhatun32 Nisa's Congregation

\begin{tabular}{lll}
\hline Types of information system facilities & Sum & $\%$ \\
\hline Congregation who have an Android phone & 17 & 85 \\
\hline Congregation who do not have an Android phone & 3 & 15 \\
\hline
\end{tabular}

32 Raudhatun Nisa, Jadwal Kegiatan Majelis Ta'lim Raudhatun Nisa. 


\begin{tabular}{lll}
\hline Congregation who have the WhatsApp application & 17 & 85 \\
\hline Congregation who has a Facebook application & 8 & 40 \\
\hline Congregations who have the Instagram application & 5 & 25 \\
\hline
\end{tabular}

Source: The interview results with the members of majelis ta'lim Raudhatun Nisa

The data in Table 5 shows that the majelis ta'lim has high innovation and motivation in learning. The innovation is in term of the means used, from not using smartphones to utilizing smartphones. So, the motivation of the congregation to learn is higher, as indicated by the media used in learning. Most members of majelis ta'lim (85\%) have smart phones and they are eager to improve their religious insight and religious skills, including by using mobile phones. The cellphone application used by the majelis ta'lim congregation are WhatsApp (85\%), facebook (40\%), and instragram (25\%). WhatsApp is considered a userfriendly application as it enables messaging and calling. Thus, the congregation of the majelis ta'lim can get any information quickly.

The second uniqueness is the place of learning. The majelis ta'lim learning is generally held in mosques or prayer rooms. The majelis ta'lim usually takes place in a mosque that is generally used as a center of activities. However, the majelis ta'lim Raudhatun Nisa does not conduct the learning at a mosque because it has its own building for the activities. The learning activities is conducted in the hall. In contrast to the other majelis ta'lim, in general, which utilizes mosques and prayer rooms as the center of activity. Besides, using the hall for learning, it also uses the house of one of the members. The use of the member's house is purely voluntary from the house owner.

The third uniqueness is that the majelis ta'lim and the Qur'an education for kids (Taman Pendidikan Al-Quran) are merged in 
the same place. The majelis ta'lim activity is scheduled once a week only (Monday), while the Qur'an education for kids is held on Tuesday to Friday.

\section{Conclusion}

Majelis ta'lim Raudhatun Nisa has conducted innovation using a mobile application, i.e. WhatsApp and Facebook. WhatsApp is used for informing the learning schedule, any sudden change, question and answer about the learning, and any information concerning learning or other activities related to majelis ta'lim. Facebook is used to inform the activities carried out by the majelis ta'lim, whether related to learning or other activities related to the majelis ta'lim. The facebook account has enabled the majelis ta'lim to be increasingly known to a wider community. This social media account is also the learning innovation concerning the use of media.

\section{References}

Abadi, Yusry. Pengembangan Wawasan Keagamaan Melalui Majlis Ta'lim Di Bandar Lampung. Jakarta: Balitbang Agama dan Diklat Keagamaan, 2002.

Alawiyah, Tuty. "Manajemen Majelis Taklim.” Jakarta: Pustaka Intermasa, 2009.

-. "Strategi Dakwah Di Kalangan Majelis Ta'lim." Bandung: Mizan, 1997.

Aminuddin, Dkk. "Pendidikan Agama Islam Untuk Perguruan Tinggi Umum.” Bogor: Ghalia Indonesia, 2002.

Aminuddin, Rasyad. "Teori Belajar Dan Pembelajaran." Jakarta: UHAMKA Press \& Yayasan PEP-Ex 8 (2003).

Anwar, Rosehan. Majelis Taklim Dan Pembinaan Umat.

Puslitbang Lektur Keagamaan, Balitbang Agama dan Diklat Keagamaan ..., 2002.

Campo, Juan Eduardo. Encyclopedia of Islam. Infobase 
Publishing, 2009.

Dokumen Raudhatun Nisa. Sejarah Pendirian Majlis Taklim Raudhatun Nisa (2018).

Ebta, Setiawan. "Kamus Besar Bahasa Indonesia." KBBI Offline, 2015.

Erliyana, Rika, and Samsul Huda. "Actualization of Pancasila Values (Indonesian Ideology) in Majelis Taklim Organization." Al-Hayat: Journal of Islamic Education 3, no. 1 (2019): 68-81.

Hidayati, Umul. "Inovasi Madrasah Melalui Penyelenggaraan Madrasah Riset.” Edukasi 17, no. 3 (2019): 294679.

Huda, Imamul. "Pemberdayaan Masyarakat Berbasis Multikultural Di Majelis Taklim An Najach Magelang." INFERENSI: Jurnal Penelitian Sosial Keagamaan 13, no. 2 (2019): 253-78.

Hussin, Anealka Aziz. "Education 4.0 Made Simple: Ideas For

Teaching." International Journal of Education and Literacy

Studies 6, no. 3 (2018): 92-98.

Kamaluddin, Kamaluddin. "Mesjid Dalam Meningkatkan

Keagamaan Masyarakat Melalui Majelis Taklim Di Kota

Padangsidimpuan." Tadbir: Jurnal Manajemen Dakwah

FDIK IAIN Padangsidimpuan 1, no. 1 (2019): 17-32.

Masturoh. "Interview with Masturoh Chip of Raudhotun Nisa." Jakarta, 2019.

Minangsih, Kalsum. "Paradigma Baru Pengelolaan Institusi

Dakwah: Urgensi Ilmu Manajemen Mewujudkan Majelis

Taklim Ideal." Kontekstualita: Jurnal Penelitian Sosial

Keagamaan 29, no. 2 (2014): 145910.

Moelong, J. "Lexy. 2012." Metode Penelitian Kualitatif.

Bandung: PT Remaja Rosdakarya, n.d.

Nugraha, Firman. "Peran Majlis Taklim Dalam Dinamika Sosial Ummat Islam.” Jurnal Bimas Islam Kemenag RI 9 (2016).

Raudhatun Nisa. Jadwal Kegiatan Majelis Ta'lim Raudhatun Nisa. Jakarta, 2018.

Rosidin, Rosidin. "INDEKS PERAN PENYULUH AGAMA DALAM MEMBINA KEHIDUPAN BERAGAMA 
KELUARGA MAJELIS TAKLIM DI KABUPATEN SRAGEN JAWA TENGAH Index of The Roles of Religion Extension Agent on Guiding Religious Life for Majlis Taklim in Sragen District Central Java." Jurnal SMART (Studi Masyarakat, Religi, Dan Tradisi) 3, no. 1 (2017): 7989.

Subandi, Muhammad. "Developing Islamic Economic Production." Science Technology and Development 31, no. 4 (2011): 348-58.

Walsh, Kieran. "Mobile Learning in Medical Education." Ethiopian Journal of Health Sciences 25, no. 4 (2015): 36366.

Winn, Phillip. "Women's Majelis Taklim and Gendered Religious Practice in Northern Ambon." Intersections: Gender and Sexuality in Asia and the Pacific 30 (2012): 115. 